\title{
Education as a Determinant of Response to Cyclone Warnings: Evidence from Coastal Zones in India
}

\author{
Upasna Sharma $^{1,2}$, Anand Patwardhan $^{3}$ and Anthony G. Patt ${ }^{2}$
}

\begin{abstract}
Education is often considered a means for enhancing adaptive capacity, based on the consideration that formal education is likely to improve the ability of individuals to evaluate risks and respond to warning information. We explore the relation between the level and nature of education and enhanced ability to respond to tropical cyclone risk. We make a distinction between formal school-based education and nonformal education in the form of traditional knowledge of environmental precursors and conditions that may be associated with tropical cyclone occurrence. We evaluate two possible routes through which education could lead to enhanced ability to respond to tropical cyclone risk; first, education, both formal and nonformal, may lead to a better ability to access, understand, and interpret warning information and hence lead to an appropriate response to the warning; and second, formal education may be associated with greater income levels and socioeconomic status and thus with greater resources for evacuating in response to cyclone warning. We find that the hypotheses regarding the link between formal education and adaptive capacity are actually not well supported by empirical data. On the other hand nonformal education in the form of traditional knowledge for predicting cyclones based on environmental precursors emerged as a significant determinant of the ability to understand and interpret warning information and provides a strong case for preserving and promoting a hazard-specific traditional knowledge base along with formal education.
\end{abstract}

Key Words: cyclones; early warnings; education; traditional knowledge base; warning-response process

\section{INTRODUCTION}

Scholars have identified targeted human and social development as an important approach to adaptation to climate change in the academic discourse (McGray et al. 2007). However, the link between human and social development and reduction in the vulnerability to climate risk is not as linear and simple as it may seem in the first instance. For example, consider the Millennium Development Goal of universal education; although the goal is commendable in itself, it may be too simplistic to assume that achievement of this goal would automatically lead to an enhancement of ability to respond to climate risk, i.e., adaptive capacity. It is important to investigate the hypothesized link between achievement of development goals and enhancement of adaptive capacity, not only from the point of view of scholarship, but also because it has practical implications for allocation of financial resources across the plethora of adaptation activities.

The question we ask is the following: Does the nature of education and the level of educational attainment lead to an improved ability to respond to current climate risks, such as tropical cyclone hazard? The extreme weather (tropical cyclone) context necessitates the use of available coping and adaptive capacity within the population at risk in which evacuation in response to early warning is one of the important options available for reducing risk of mortality. We identify two causal pathways to evaluate whether the level of educational attainment is a determinant of evacuation in response to cyclone early warning. First, for warnings to be useful, people need to correctly interpret and understand the information. We hypothesize that the level of educational attainment of the warning recipient ought to improve understanding and interpretation, and lead to more appropriate decisions with respect to evacuation. However, we make a distinction between different kinds of education based on the definition provided by La Belle (as cited in Mazza 2007:2) in which formal education is the "purposive and structural learning leading to recognized certificates and diplomas," which differs from nonformal education, i.e., "any educational activity taking place outside the formal system" and informal education, i.e., "the unplanned learning that goes on in daily life." This is because formal education is only one kind of education a person may receive, particularly in the context of rural communities in developing countries where the reach of formal education is not universal even today. Even in the areas where formal education has reached, the levels of formal education attainment and often the quality are not very high for a variety of reasons. Nonformal education, different from formal education and much more specific to the hazard itself, often results from experience and knowledge being passed down through generations. For example, some fishermen are able to anticipate the occurrence of cyclones based on environmental precursors they observe before the manifestation of the cyclone, like change in direction of winds, changes in animal and plant behavior, changes in the color of the sea, etc. We term this as the traditional knowledge base on predicting cyclones based on environmental precursors. We hypothesize that this traditional knowledge base for predicting 
cyclones is likely to influence response to cyclone risk and also interpretation and understanding of the cyclone warning messages sent by the meteorological department.

Second, correct interpretation and understanding of the warning message is only one aspect of responding to warning. For actual evacuations, resources are needed. We hypothesize that the level of formal education ought to improve income levels and access to resources for evacuation and thus to facilitate response in terms of evacuation. We examine the evidence that relevant literature provides with respect to our hypotheses about the effect of education on adaptive capacity or the ability to respond to risk.

\section{BACKGROUND}

Many studies provide evidence for a positive correlation between formal education and desirable life outcomes such as income (Angrist and Krueger 1991, Hanushek and Kimko 2000, Barro 2001, Barro and Lee 2001, Soto 2006, Cohen and Soto 2007, Jamison et al. 2007), life-expectancy and health (Caldwell 1979, Cochrane et al. 1980, Adams et al. 2003), well-being (Oreopoulos 2003, Oswald and Powdthavee 2007), civil and political participation (Verba et al. 1995, Nie et al. 1996), and of a negative correlation with many undesirable behaviors such as substance abuse (Baker et al. 2011) and criminal activities (Lochner 2004). The question of causality, however, remains unresolved. One hypothesis is that education builds human capital by creating both specific, jobrelated skills and a more generalized increase in cognitive capacities, causing increased income, health, and political participation, among many positive outcomes (Becker 1964, Lutz and KC 2011). A second hypothesis suggests that it is inherent abilities that lead to positive outcomes, and that education itself may do little to enhance those abilities; rather, it is those with the inherent abilities who want to and are able to complete formal education. In this way, Spence (1973) and Stiglitz (1975) suggested that formal education signals inherent abilities, to society in general and potential employers more specifically. Most likely both hypotheses hold, i.e., education has some independent effect on positive life outcomes, while also being affected by some other factors that also impact life outcomes.

Rather than examining the entire range of life outcomes with which education seems to be correlated, we focus on two strands of literature: first, the way formal education has been treated in the climate change adaptation and disaster management literature and more specifically in the warningresponse literature; and second, the literature on traditional knowledge-based weather forecasting.

\section{Formal education as a determinant of climate adaptive capacity}

In recent years, the question of what constitutes adaptive capacity to climate change risk has brought to fore the role of education as an important factor in determining the coping or adaptive capacities of a population (e.g., UNDP 2004). Most studies (Adger et al. 2004, Toya and Skidmore 2007, Blankespoor et al. 2010, Patt et al. 2010) that have examined education as an indicator of adaptive capacity to current climate risk and climate change have used national level mortality (or other impacts) data on climate related disasters (mostly from the CRED International Disaster Database) as the dependent variable. Many of these studies show that formal education is negatively correlated with deaths or other forms of loss from disasters and the correlation seems to be particularly strong for developing countries. Many different indicators of formal education have been used in these studies such as literacy rates among different age groups (Adger et al. 2004); female to male literacy ratio (Adger et al. 2004); number of years of schooling (Toya and Skidmore 2007); and female educational enrollment rate (Blankespoor et al. 2010). At a finer scale, researchers have examined education as one of the factors leading to adoption of improved strategies for coping with climate impacts in the agriculture sector. A higher level of education appears to be associated with access to information on improved technologies and productivity consequences (Norris and Bati 1987). Evidence from various sources indicates that there is a positive relationship between the education level of the household head and the adoption of improved technologies (Igoden et al. 1988, Lin 1991) and adaptation to climate change (Maddison 2006). Therefore, farmers with higher levels of education are more likely to better adapt to climate change (Deressa et al. 2008). Other studies (e.g., Clay et al. 1998) provide contradictory evidence, suggesting that education does not correlate with reduced vulnerability and greater adaptation.

Moving from general disaster vulnerability as the dependent variable to the propensity to respond in particular ways to extreme event risk, researchers have looked at education as one of several determinants. There is a rich empirical literature base examining the effect of the warning message itself, the credibility of the warning, channels of warning, environmental cues (both social and physical), resources, cognitive factors, and physiological factors (see annotated bibliography by Mileti et al. 2006). The evidence regarding the particular effect of education on response to warning has been mixed. In general, most studies (Edwards 1993, Farley et al. 1993, Liu et al. 1996, Balluz et al. 2000) have found a positive correlation between education and evacuation (response to warning). Interestingly, Farley et al. (1993) find that the lower the education a person has, the more likely they are to 'believe' the warning, though in terms of responding to warning they find a positive correlation with education. Turner et al. (1979, 1981) find that the more education a person has, the more likely they are to understand a warning message; however, understanding may not necessarily lead to response because response would require resources, but it definitely facilitates 
response, given the resources. However, a few studies find no relationship between education and a person's likelihood of responding to a warning message (Mileti et al. 1993, Miltei and DeRouen Darlington 1997, Bateman and Edwards 2002, Patt et al. 2005). In most warning-response studies education has only been used as a control variable in a regression equation and was of interest only indirectly, or as a means of simply indicating whether or not a respondent was educated or the level of a respondent's education, without much investigation into education as an explanatory factor. Consequently, research that examines variations in evacuation specifically in the context of varying levels of formal education seems to be scarce.

\section{Nonformal education (traditional knowledge) in disaster management and climate change adaptation research}

A number of studies have documented the use of traditional knowledge by farmers for understanding the weather and climate patterns to make decisions about cropping and irrigation. These document three broad kinds of indicators used by people to predict climate and weather-related parameters such as rainfall and extreme events. The first kind of indicators are the 'hydro-meteorological' indicators based on observations of certain weather-related parameters such as wind direction, temperature, rainfall, etc., by farmers and other people with nature-dependent livelihoods a few hours, days, or months in advance of the actual weather occurrence (for example, Kanani and Pastakia 1999, Singh and Dorjey 2004, Anandaraja et al. 2008, Irfanullah and Motaleb 2011, Pareek and Trivedi 2011, Sethi et al. 2011). The second category of indicators refers to a number of different 'bioindicators' based on phenology of certain local flora and behavior of certain local fauna before the actual occurrence of a weather event (for example, Samati and Begum 2006, Teron and Borthakur 2009, Acharya 2011, Chinlampianga 2011, Mao and Hynniewta 2011, Nedelcheva and Dogan 2011, Singh 2011). The third category of indicators is based on the traditional almanacs used in many places in India for making agricultural decisions (for example, Angchok and Dubey 2006, Sivaprakasam and Kanakasabai 2009, Vandeep et al. 2012). Although some studies have focused on a particular category of indicators, others have documented the use of two or more these categories (Kanani and Pastakia 1999, Anandaraja et al. 2008, Sethi et al. 2011, Pareek and Trivedi 2011).

Although most studies simply document the different kinds of traditional knowledge and practices used by various communities, tribes, and groups in the country, some studies even attempt to compare forecasts about weather and climate made by using these traditional knowledge-based indicators to actual weather events (Angchok and Dubey 2006, Sivaprakasam and Kanakasabai 2009, Vandeep et al. 2012). A few studies even compared the traditional knowledge-based forecast to the forecast of the meteorological department for the same period to see which forecast predicted the actual weather event more accurately (Rengalakshmi 2006).

Most studies on the use of traditional knowledge to predict weather and climate have been in the domain of agriculture and decisions related to cropping and irrigation. Except for the Westgate (1978) study, in which there is some documentation of the environmental precursors observed by certain island people in the Commonwealth of Bahamas to anticipate the occurrence of a hurricane, we did not find any other study that examines the use of traditional knowledge for decision making for evacuation in response to an extreme weather event like a tropical cyclone. There is some mention in the grey literature of tribal people in the Andaman and Nicobar islands being able to evacuate to safer places in time through the use of their traditional knowledge for predicting a disastrous event during the 2004 Indian Ocean Tsunami but we did not find any systematic treatment of this subject in scientific literature.

We did find one study (Rengalakshmi 2006) that examines the interaction of two knowledge systems, i.e., the scientific and the traditional, based on an experiment in a few villages in Tamil Nadu by MS Swaminathan Research Foundation. The study found that the scientific forecast and the traditional forecast both can be used by the farmers in a complementary manner; as in this case study, they tended to predict different meteorological aspects. For example, the scientific forecast predicted the probabilistic amount of rainfall during a period of time whereas the traditional forecast predicted the onset date of the rainfall. The experiment, which is still ongoing, provides the time and context for translating the forecast in the language and terminology understood by the farmers, but in rapid onset events like cyclones that might be difficult to achieve.

However, there appears to be no treatment in literature on whether the possession of traditional knowledge for forecasting weather and climate would have an effect on the interpretation, understanding of, and response to a modern scientific warning that is sent usually by the meteorological department. We attempt to elaborate on this issue.

In sum, there is a knowledge gap concerning the effects of education on the ability to respond to climate risk, i.e., adaptive capacity, but there is reason to hypothesize a causal relationship involving three different routes. First, formal education may lead to better understanding and interpretation of relevant risk information, e.g., cyclone warning messages. Second, hazard-specific nonformal education, i.e., traditional knowledge for predicting cyclones, may lead to better response to cyclone risk, i.e., through evacuation, and also a better understanding and interpretation of cyclone warning messages sent by the meteorology department. Third, a higher level of formal education is associated with a higher 
socioeconomic status and more lifetime earnings (e.g., Cutter et al. 2003, Wisner et al. 2003), and education can thus be seen to reduce disaster risk through the link between income, socioeconomic status, livelihoods, and risk. Therefore, we test whether the abovementioned three linkages leads the better educated to respond more effectively to cyclone risk.

\section{METHODOLOGY}

The purpose of this research is to investigate the relationship between education and evacuation in a sample of coastal residents that encountered tropical cyclones 'Fanoos' and 'Ogni.' The household survey data used here were originally collected for the analysis of a range of factors that affect household-level evacuation pattern in response to cyclone warning (Sharma 2009). They were not collected specifically to examine the influence of education, formal or traditional, on evacuation decision. However, the data do allow us to examine a mix of respondent and warning system attributes and their relationship to whether education affected the respondents' decision to evacuate or not.

The cyclonic storm Fanoos crossed near Vedaranyam, in Nagapattinam district of Tamil Nadu at 1100 hours on 10 December 2005. The cyclonic storm Ogni made landfall near Bapatla in Guntur district of Andhra Pradesh at 1300 hours on 30 October 2006. For each of these events, the India Meteorological Department (IMD) prepared and issued early warnings to state and district authorities responsible for disaster management. An example of the actual warning for cyclone Ogni prepared by IMD and sent to the Cyclone Warning Centre (CWC) at the state level is given below:

Two stage warning (.) Cyclone warning bulletin no. 3 issued by cwc vishakapatnam at 0400 hrs ist of 30-10-2006 (.) Cyclone warning for the districts of prakasam, guntur, krishna, east godavari \& west godavari and vishakhapatnam distircts (.)

The cyclonic storm Ogni over the westcentral Bay of Bengal moved northward and lay centred at 2330 hrs ist of y/day the 29th october 2006 near latitutde 15.5 degrees north and longitude 80.5 degrees east about $50 \mathrm{kms}$ east of ongole (.) It is likley to move in a northernly direction and cross andhra coast between ongole and machilipatnam by morning of today the 30th (.)

Under its influence rainfall at most places with heavy to very heavy falls likely at a few places and extreme heavy falls at one or two places likely over coastal ap during the next 24 hrs (.) Gale winds speed reaching 70 to $80 \mathrm{kmph}$ likely along and off coastal areas of above districts, breaking off tree branches and causing some damages to kutcha houses (.)

Tidal waves one to one decimal five mts above normal tide likely inundate coastal areas of above districts during the same period (.) State of sea will be high to very high (.) Fishermen advised not to venture into the sea (.) Danger signal no. 7 hoisted at vadarevu and nizampatnam ports (.) Danger signal no. 6 hoisted at machilipatnam and kakinada ports (.) Local cautionary signal no. 3 kept hoisted at krishnapatnam, vishakhapatnam, bheemunipatnam and kalingapatnam ports (.) The above warning is for prakasam, guntur, krishna, east godavari and west godavari and vishakhapatnam distircts (.) All cis only (.) Convey this message through v.h.f. sets to pass all the concerned p.s.s. (.)

The warnings were disseminated through a complex set of communication channels, involving the media, public address systems, and face to face communication. The illustrative warning message given above was intended for the different authorities playing a role in warning dissemination and evacuation such as state and district disaster management authorities, fisheries department, etc. Often by the time a warning reached the last mile, i.e., the population at risk, it was modified in attempts by different authorities to simplify it for the layman or because certain media, e.g., public address systems, were conducive to simplified versions of the above message. Details on how the warning language got modified in the process of dissemination are described in Sharma (2009). Though both Fanoos and Ogni had weakened into a deep depression just before crossing land, it was confirmed from the relevant district collectors that evacuation orders had been given in many coastal villages and low-lying areas before landfall.

\section{Study area and sampling}

In case of Fanoos, Nagapattinam district and the adjoining Cuddalore district were affected. In the case of Ogni, Guntur and its adjoining districts, Krishna and Prakasam, were the affected districts. Within each of these districts, we chose those subdistrict units ('talukas' in Tamil Nadu, and 'mandals' in Andhra Pradesh) and villages within these talukas and mandals where evacuation orders had been given by local authorities. We identified these locations in consultation with the district administration. In all we selected a set of 34 villages to sample (Fig. 1) a number of variables being studied in the larger project (see Sharma 2009) of which our results here represent one part. Within each village, the strategy for selecting households was purposive convenience sampling, keeping in mind aspects such as gender, age, and minority groups in the village, so that the sample was as representative of the population as possible. Within the household, the respondent that was chosen was generally the head of the household or in absence of the head of the household, the person who would be the decision maker, which could be the wife, the mother, eldest son, or eldest daughter. Generally we collected four to eight responses per village. 
Fig. 1. Location of the study area on the map of Andhra Pradesh and Tamil Nadu, India.

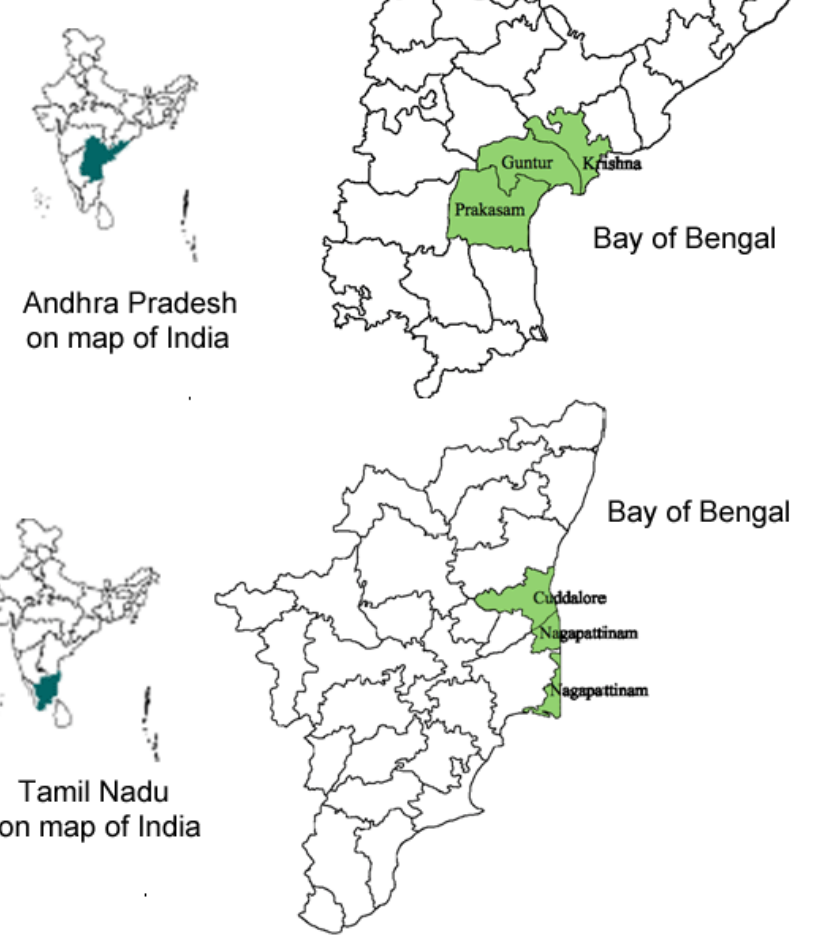

(Map not to scale, only for illistrative purposes)

\section{Survey instrument}

The survey instrument (questionnaire) had originally been developed in English. This questionnaire was first translated into Tamil and Telugu, the local languages in Tamil Nadu and Andhra Pradesh, respectively, and then it was translated back into English to check for discrepancies in terms and meanings that were then corrected in the Tamil and Telugu versions of the questionnaire. The questionnaire was administered orally with the help of interpreters because a substantial proportion of the population in the coastal villages is illiterate. The interpreters were first sensitized to the objective of the survey and the items in the questionnaire were explained to them. This interaction with the interpreters also served as a pretesting of the questionnaire because a few questions were modified on the basis of the feedback given by the interpreters after a detailed discussion about how the meaning of a question may be interpreted when administered to the sample. Ethical procedures about informing respondents on consent and confidentiality were followed. This was especially important to avoid misunderstandings, because the language interpreters who accompanied were often, though not always, from the revenue services. If the purpose of the study, informed consent, and confidentiality issues were not properly and convincingly addressed in the beginning then the respondents may have been reluctant to talk freely. It took about 45 minutes to 1 hour to administer one questionnaire.

The questionnaire asked people whether they had evacuated in the most recent event, i.e., Fanoos or Ogni, and also covered several aspects of the hurricane event including questions on warning message content, clarity, timing, and frequency of warning, perceptions of people on physical and social environmental cues, their previous hurricane experience, their socioeconomic status, and demographic factors (Sharma 2009 has complete details of the study).

\section{Relevant variables and their indicators}

The relevant variables given the research question and hypothesis of this study were: appropriate response to warning; formal education; traditional knowledge for predicting cyclones based on environmental precursors; income and socioeconomic status; access to, understanding of, and interpretation of the cyclone warning message.

The appropriate response to the warning was deemed to be evacuation because the discussions with the district authorities (district collector and the revenue department) confirmed that the intensity of cyclones Ogni and Fanoos were considered severe enough that they had given evacuation orders in many coastal and other villages at risk, including the villages in our sample. Therefore, first, the respondent was asked a straightforward question: "Did you evacuate your home/village to go to a safer place (for cyclone Fanoos/Ogni)?" The response was elicited as binary 'yes' or 'no.' This variable was termed as 'evacuation.'

For the respondents who evacuated, another question was asked: "Were you physically forced to evacuate or did you evacuate voluntarily?" with a binary response of 'yes' or 'no. ' In computing the total number of evacuees, we treated the people who were forced to evacuate as nonevacuees and hence term this variable as 'voluntary evacuation.' There were some respondents who reported that they did evacuate, but they did not evacuate to a cyclone shelter or a relief shelter; this may have been because they evacuated at the last moment and did not have time to reach a cyclone shelter or perhaps because they did not have the transportation to go to a shelter. In this case, these people took refuge in the concrete house of a neighbor or a concrete church or school building within the village. The above-mentioned two questions do not make a distinction between evacuation to a relief or cyclone shelter and simply evacuating to a neighborhood building, which may be more robust than the respondent's own house. If we make the definition of evacuation stricter and consider respondents who did not evacuate to a cyclone or relief shelter as nonevacuees, then we have another variable for evacuation. We simply combined voluntary evacuees (defined above) and 
shelter evacuees and termed the variable as 'voluntary shelter evacuation.' Thus, people who were forced to evacuate and people who did not evacuate to a cyclone shelter or a government relief shelter were considered nonevacuees.

Level of formal education was elicited by asking the respondent what level of school and/or college they had attained. A traditional knowledge base for predicting cyclones based on environmental precursors was elicited by asking the respondent the following open-ended question: "What cues in the environment did you observe before the actual manifestation of the cyclone that indicated the occurrence, severity, or timing of the cyclone?" Based on people's responses, we converted this to a categorical variable indicating whether a respondent possessed traditional knowledge on predicting cyclones in at least some measure.

Information about income and socioeconomic status was elicited by simply asking about the total household income of the respondent. In this study, income was self-reported, therefore was likely underreported. Income and socioeconomic status were also captured through another indicator, i.e., housing quality. The respondent was asked in what kind of house he or she lived. Based on the material of house construction most respondents lived in one of three kinds of houses, mud brick house with thatched roofs, house with tiled roof with walls of varying kinds of materials, and house made of concrete material, also called "pucca" houses or buildings. The first kind was considered the poorest quality in terms of protection from a cyclonic storm and concrete houses were considered the best for protection against the storm.

The survey questionnaire elicited information on the 'channels' through which warning information was received by the respondents; the 'contents' of the warning message as recalled by the respondents; the 'clarity' of the message, i.e., how clearly the message was understood by the respondents; and respondents' estimate of the damage the cyclone might cause. The means by which a warning was delivered clearly had implications for access, e.g., a warning on television may have been heard by relatively fewer people than a warning on a public address system in the rural Indian context where the penetration of televisions was still low in the years 2005 and 2006. The question of 'content' of the warning message covers two aspects: (1) access, because better access would mean getting more and better quality information; and (2) understanding, because given the access conditions, a better recall of the warning information at the time of the survey would mean the message was better understood. The 'clarity' of the warning message also captures the understanding of the warning. A respondent's estimate of damage due to a cyclone of a particular severity reflects the interpretation of the warning message by the warning recipient and is often a factor in decisions about evacuation. Specific questions on access, understanding, and interpretation of warnings were as follows:
The following question was asked to elicit the contents of the warning message people received: "Did the warning message include:"

1. The severity of the cyclone in terms of wind speed and storm surge? (yes/no)

2. The likely location of landfall? (yes/no)

3. The likely time of landfall? (yes/no)

4. The order for evacuating your home? (yes/no)

5. Where and how to go when evacuating? (yes/no)

The following question was asked to elicit information on the clarity of the warning: "In your opinion how many words did you understand in the warning message?" (none/few/all)

For channels through which they received the warning communication, the following eleven options were provided in the questionnaire, from which the respondents could choose one or more:

1. Village secretary

2. A messenger from the revenue department

3. A messenger from fisheries department

4. Church father

5. NGO personnel

6. Heard from neighbors/family/friends/other community members

7. Public address system

8. Television

9. Radio

10. Newspaper

11. Any other (please mention)

Estimate of damage due to a cyclone of particular severity was captured through the following open-ended question with qualitative responses: "What impacts/damage do you think could occur due to the cyclone of severity (' $\mathrm{x}$ ' $\mathrm{km} / \mathrm{hr}$ wind speed and ' $y$ ' $\mathrm{m}$ storm surge) mentioned in the warning?" Actual numerical values of wind-speed and storm surge mentioned in the meteorological department warning were used in the questionnaire instead of ' $\mathrm{x}$ ' and ' $\mathrm{y}$.'

\section{Sample characteristics}

Of the 237 survey responses we obtained, 212 were sufficiently complete to include in our sample. This was large enough to allow us to test the statistical significance of relationships between education, evacuation, and the variables mentioned above. The sample consisted of $61 \%$ male 
respondents and 39\% female respondents. Fishermen accounted for $41 \%$ of respondents, $22 \%$ were agricultural laborers, $16 \%$ were agricultural landowners, and about $21 \%$ were engaged in other occupations such as weaving or trade. The age of the respondents ranged from 18 to 80 years, with the median age of 36 years.

\section{Methods for data analysis}

We tested for two effects: first, whether formal education and traditional knowledge were predictors of evacuation. To do this we regressed evacuation against formal education and against traditional knowledge separately. Because our dependent variable 'evacuation' was a binary categorical variable we used logistic regression for our analysis.

Second, we tested for interactive effects between education and other potential determinants of evacuation, i.e., we regressed evacuation against evacuation predictors (income and socioeconomic status, and access, understanding, and interpretation of warning information) for different levels of formal education, and for the presence and absence of nonformal education or traditional knowledge. Because the dependent variable 'evacuation' was a binary categorical variable, we used logistic regression.

Testing for interactive effects enables us to identify more complex relationships between education and evacuation. For example, a variable might have a positive effect on evacuation among the educated, but a negative one among the illiterate, or vice versa. These opposing effects would essentially cancel each other out, so that in the analysis of the full sample the variable would appear to have no effect on evacuation, or a variable might have a stronger effect on evacuation among the educated and a weaker or no effect among the illiterate, or vice versa. The differences in the strength/magnitude of the effects could mean that in the full sample analysis the variable may appear to have a weaker or no effect on evacuation. This kind of analysis would help in identifying differences in the way the income and social status predictors and information and warning message predictors matter across different categories of education

\section{RESULTS}

We present the results of data analysis, first with a summary of the frequencies of responses for variables used in the study (Table 1), and then with the logistic regression analyses conducted.

\section{Education and evacuation}

First, we regressed education on evacuation to test whether education had any explanatory power for appropriate response to warning. We used two variants of indicators for the variable 'formal education:' first, the number of years of formal education that a person had received. Number of years of education ranged from 0 years to 17 years with the median being 7 years of education. Second, we converted the number of years of education into a categorical variable with three categories: the first category was 'illiterate' and comprised 43 respondents who reported receiving 0 years of education; the second category comprised 127 respondents who reported receiving between 1 to 10 years of education; and the third category comprised 42 respondents who reported receiving 11 or more years of education. The hazard specific nonformal education or traditional knowledge base for predicting cyclones was converted from an open ended question into a binary categorical variable with two categories being, 'people who possessed no traditional knowledge to predict cyclones' and 'people who possessed some measure of traditional knowledge for predicting cyclones'. Table 2 presents the results of regressing evacuation against each of the three indicators mentioned above.

Table 2 shows that as the definition of evacuation was made stricter, i.e., people who were forced to evacuate and people who did not evacuate outside the village were counted as nonevacuees, the effect of formal education on evacuation first diminishes and then becomes completely insignificant. This implies that among the people who were forced to evacuate there were a relatively large number of formally educated people. Also people who did not evacuate outside the village but took shelter in a "pucca" building within the village also consisted of a relatively larger number of educated people. This was probably because the more educated people had higher incomes and therefore better quality housing, or better access to quality housing; the significant and positive association between formal education and income and formal education and housing quality in Sharma (2009) supports this. Table 2 shows that the odds of evacuation for people who possessed even some measure of traditional knowledge for predicting the occurrence of cyclones were much higher than the odds of evacuating for people without any traditional knowledge base.

\section{Interactive effects}

We tested the strength and direction of evacuation predictors across different categories of formal education. For this we first examined the effect of predictor variables, i.e., income and socioeconomic status, and access, understanding, and interpretation of the warning message on evacuation among the full sample, and then separately for respondents with different levels of formal education (Table 3 ).

Income did not have a significant influence on evacuation, neither for the whole sample nor for different levels of education. Housing quality did not seem to significantly influence evacuation when considering the complete sample of respondents. However, it had a significant and negative influence on evacuation among the higher educated respondents, i.e., better housing quality meant less evacuation. The kind of effect housing quality had on illiterate and educated respondents was notably different: housing quality 
Table 1. Summary of variables used in the analysis

\begin{tabular}{|c|c|c|c|}
\hline Indicators of interest & \multicolumn{2}{|l|}{ Categories of response } & Distribution of responses \\
\hline \multicolumn{4}{|l|}{ Response to warning } \\
\hline \multirow[t]{2}{*}{ Evacuation } & \multicolumn{2}{|l|}{ Not evacuated } & $75(35.4 \%)$ \\
\hline & \multicolumn{2}{|l|}{ Evacuated } & $137(64.6 \%)$ \\
\hline \multirow[t]{2}{*}{ Voluntary evacuation } & \multicolumn{2}{|l|}{ Not evacuated } & $89(42 \%)$ \\
\hline & \multicolumn{2}{|l|}{ Evacuated } & $123(58 \%)$ \\
\hline \multirow[t]{2}{*}{ Voluntary Shelter evacuation } & \multicolumn{2}{|l|}{ Not evacuated } & $118(55.7 \%)$ \\
\hline & \multicolumn{2}{|l|}{ Evacuated } & $94(44.3 \%)$ \\
\hline \multicolumn{4}{|l|}{ Education } \\
\hline Formal education & \multicolumn{3}{|c|}{ Range: 0 to 17 years; Median: 7 years } \\
\hline \multirow{2}{*}{ Hazard specific traditional knowledge base } & \multicolumn{2}{|c|}{ Couldn't tell anything } & 111 \\
\hline & \multicolumn{2}{|c|}{$\begin{array}{l}\text { Reported observing cues and could provide some or more detail } \\
\text { on the cues }\end{array}$} & 101 \\
\hline \multicolumn{4}{|l|}{ Income and socioeconomic status } \\
\hline Income & \multicolumn{2}{|c|}{$\begin{array}{l}\text { Range: INR } 3000 \text { p.a. to INR } 60,000 \text { p.a. } \\
\text { Median: INR } 12,000 \text { p.a. }\end{array}$} & \\
\hline \multirow[t]{3}{*}{ Housing Quality } & \multicolumn{2}{|c|}{ Thatched huts } & 113 \\
\hline & \multicolumn{2}{|l|}{ Tiled roof house } & 20 \\
\hline & \multicolumn{2}{|l|}{ Concrete roof house } & 79 \\
\hline \multirow{2}{*}{\multicolumn{4}{|c|}{$\begin{array}{l}\text { Indicators related to access, understanding, and } \\
\text { interpretation of warning information } \\
\text { Whether the following were included in } \\
\text { the warning message: }\end{array}$}} \\
\hline & & & \\
\hline \multirow[t]{2}{*}{ Severity of cyclone } & No & & 61 \\
\hline & Yes & & 151 \\
\hline Landfall Location of cyclone & No & & 66 \\
\hline & Yes & & 146 \\
\hline Landfall time of cyclone & No & & 74 \\
\hline & Yes & & 138 \\
\hline Evacuation order in the warning & No & & 36 \\
\hline & Yes & & 176 \\
\hline Protective guidance in the warning & No & & 81 \\
\hline & Yes & & 131 \\
\hline Clarity of the warning message & & & \\
\hline (Whether all or few words understood?) & A few & & 82 \\
\hline & All & & 130 \\
\hline $\begin{array}{l}\text { Type of channel through which warning was } \\
\text { received }\end{array}$ & Face to face channels & Village Secretary & 104 \\
\hline & & Revenue dept. official & 44 \\
\hline & & Fisheries dept. official & 27 \\
\hline & & Church person & 10 \\
\hline & & NGO personnel & 18 \\
\hline & & Community members & 42 \\
\hline & Media Channels & Public address system & 48 \\
\hline & & Television & 99 \\
\hline & & Radio & 71 \\
\hline & & Newspaper & 37 \\
\hline & & Others & 21 \\
\hline $\begin{array}{l}\text { Estimate of damage due to cyclone given a } \\
\text { particular severity }\end{array}$ & $\begin{array}{l}\text { Either some vague esti } \\
\text { damage }\end{array}$ & of damage or could not estimate & 88 \\
\hline & Some concrete estimat & damage & 124 \\
\hline
\end{tabular}

had a negative effect on evacuation in case of the educated, whereas in the case of the illiterate, housing quality had a positive though insignificant effect on evacuation, i.e., even with better housing quality there were greater odds of evacuation among the illiterates.

Warning message contents mattered. Four of five indicators, i.e., cyclone severity, landfall location, landfall time, information on where and how to evacuate (protective guidance) were significant predictors of evacuation; among the whole sample of respondents, those who reported having received information on severity of the cyclone, landfall time, landfall location, and protective guidance had greater odds of evacuating than those who did not report receiving information on cyclone attributes. However, message content (severity of cyclone, landfall location, landfall time, protective guidance) had significant effect on evacuation for the respondents who 
Table 2. Bivariate logistic regression of formal education and traditional knowledge base on evacuation.

\begin{tabular}{|c|c|c|c|}
\hline Education (formal and nonformal) & Evacuation & Voluntary evacuation & Voluntary shelter evacuation \\
\hline Number of years of education & $1.055^{*}$ & $1.051^{*}$ & 0.998 \\
\hline \multicolumn{4}{|c|}{ Education (categorical): with 0 years of education as reference } \\
\hline Education between 1 to 10 years & 1.006 & 0.804 & 0.619 \\
\hline Education between 11 to 17 years & $2.779 * *$ & $2.304^{*}$ & 1.05 \\
\hline \multicolumn{4}{|c|}{ Education (categorical): with 1 to 10 years of education as reference } \\
\hline Zero years of education & 0.993 & 1.243 & 1.61 \\
\hline Education between 11 to 17 years & $2.76 * *$ & $2.866^{* *}$ & 1.7 \\
\hline \multicolumn{4}{|c|}{ Traditional knowledge base on predicting cyclones based on environmental precursors } \\
\hline & $1.914^{* *}$ & $2.384 * * *$ & $1.743^{* *}$ \\
\hline \multicolumn{4}{|c|}{$\begin{array}{l}\text { The number in the cells are exponentiated betas or odds ratios. An odds ratio of } 1 \text { (or not significantly different from } 1 \text { ) indicates no effect. An odds ratio } \\
\text { larger (or smaller) than } 1 \text { indicates factor by which odds of evacuation are increased (or decreased) by one unit change in independent variable. *,**, } * * * \\
\text { represent the level of significance (alpha) } \\
* * * \text { implies alpha } \leq 0.01 \\
* * \text { implies alpha } \leq 0.05 \\
* \text { implies alpha } \leq 0.10\end{array}$} \\
\hline
\end{tabular}

had an education of between 1 and 10 years. The message content had no effect on evacuation for the illiterates or for the higher educated (11 years and above) respondents. This seems strange and counterintuitive. Simply receiving an evacuation order did not seem to influence evacuation either for whole sample or for different levels of education.

Clarity of warning also significantly and positively influenced evacuation for the sample as a whole. However, when considering the influence of this factor by level of education, it had a notably stronger and a significantly positive effect on evacuation among the illiterates and higher educated respondents, but did not significantly influence evacuation in case of respondents who received an education of between 1 and 10 years. This also seems strange and counterintuitive.

Type of channel had a significant influence on evacuation for the sample as a whole. However, it had a significantly strong effect on evacuation for the illiterate category of respondents. For the illiterate category, respondents who receiving a warning face to face were 3.89 times more likely to evacuate than the respondents who received a warning from media channels.

Estimate of damage of the cyclone had a significant influence on the sample as a whole. However, it had a significantly strong effect on evacuation for the illiterate category of respondents, but did not seem to significantly influence evacuation in the case of educated respondents.

We also tested for interactive effects for having a traditional knowledge base as we did for formal education, i.e., we first examined the effect of predictor variables on evacuation among the full sample $(\mathrm{N}=212)$ and then separately for respondents with and without traditional knowledge for predicting cyclones based on environmental precursors (Table
4). We did this analysis only for variables related to the warning message and interpretation of warning and not for income and housing quality because we do not expect possession of traditional knowledge for predicting cyclones to have an effect on income and housing quality in general.

With the exception of protective guidance, the warning message characteristics and the ability to estimate damage significantly and positively influenced evacuation among the respondents who possessed traditional knowledge and did not affect evacuation for the respondents who did not possess traditional knowledge (Table 4). Among the respondents without a traditional knowledge base, what mattered most were the instructions on where and how to evacuate.

A cross-tabulation (Table 5) of education and possession of some traditional knowledge for predicting cyclones based on environmental precursors showed that a greater proportion of both the illiterate and higher educated (11 or more years of education) people did not possess the traditional knowledge to predict cyclone occurrence based on environmental precursors compared to the medium educated people ( 1 to 10 years of education). In case of higher educated people, it is understandable that traditional knowledge may not get passed on to them as they pursue higher education instead of their traditional vocations. In the case of illiterates, the reason a smaller proportion of people possessed traditional knowledge might be because most of them did not possess assets such as boats or land and were often laborers on the farms or in the fishing trade. Traditionally they did not really need this knowledge base. Qualitative interviews had revealed that people who possessed traditional knowledge tended to be fishing boat owners and agricultural landholders, i.e., people who possessed livelihood assets that could be at stake during a cyclone. Most of these people had the means to receive some 
Table 3. Bivariate logistic regression of evacuation predictors on evacuation among all respondents and separately by level of education.

\begin{tabular}{|c|c|c|c|c|}
\hline \multirow[b]{2}{*}{ Independent variables } & \multicolumn{4}{|c|}{ Voluntary shelter evacuation } \\
\hline & $\begin{array}{l}\text { All respondents } \\
\quad(\mathrm{N}=212)\end{array}$ & $\begin{array}{l}\text { Illiterate } \\
(\mathrm{N}=43)\end{array}$ & $\begin{array}{c}\text { Educated } \\
1 \text { to } 10 \\
(\mathrm{~N}=127)\end{array}$ & $\begin{array}{r}\text { Educated } \\
11 \text { to } 17 \\
(\mathrm{~N}=42)\end{array}$ \\
\hline \multicolumn{5}{|l|}{ Income and socioeconomic status } \\
\hline Income & 1 & 1 & 1 & 1 \\
\hline Housing Quality & 0.66 & 2.67 & 0.59 & $0.222 * * *$ \\
\hline \multicolumn{5}{|l|}{$\begin{array}{l}\text { Indicators related to access, understanding, and } \\
\text { interpretation of warning information }\end{array}$} \\
\hline Severity of cyclone & $2.42 * * *$ & 2.43 & $3.13 * *$ & 1.83 \\
\hline Landfall location of cyclone & $2.61 * * *$ & 2.55 & $2.91 * *$ & 2.27 \\
\hline Landfall time of cyclone & $2.35 * * *$ & 2.55 & $2.66 * *$ & 1.75 \\
\hline Evacuation order in the warning & 1.51 & 1.41 & 1.83 & 1.5 \\
\hline Protective guidance in the warning & $2.28 * * *$ & 2.36 & $2.64 * *$ & 1.75 \\
\hline Clarity of the warning message & $2.36 * * *$ & $3.74 * *$ & 1.51 & $6.67 * *$ \\
\hline Type of channel & $2.036^{* *}$ & $3.89 *$ & 1.74 & 1.93 \\
\hline $\begin{array}{l}\text { Estimate of damage due to cyclone given a particular } \\
\text { severity }\end{array}$ & $1.73 * *$ & $2.89^{*}$ & 1.58 & 1.25 \\
\hline \multicolumn{5}{|c|}{$\begin{array}{l}\text { The number in the cells are exponentiated betas or odds ratios. An odds ratio of } 1 \text { (or not significantly different from } 1 \text { ) indicates no effect. An odds rat } \\
\text { larger (or smaller) than } 1 \text { indicates factor by which odds of evacuation are increased (or decreased) by one unit change in independent variable. *,**, * } \\
\text { represent the level of significance (alpha) } \\
* * * \text { implies alpha } \leq 0.01 \\
* * \text { implies alpha } \leq 0.05 \\
* \text { implies alpha } \leq 0.10\end{array}$} \\
\hline
\end{tabular}

education (between 1 to 10 years), though often they tended to continue in their vocations instead of pursuing higher education. Hence, traditional knowledge got passed from one generation to another in many cases, though in general there has been a decline in the prevalence and use of traditional knowledge.

\section{DISCUSSION}

Our results provide evidence for the relationship between education and the ability to respond to climate risk. We consider both formal school education and nonformal education, i.e., hazard specific traditional knowledge to predict the hazard (cyclones). Adaptive capacity is represented by the ability to respond appropriately to tropical cyclone risk, i.e., to evacuate in response to the cyclone early warning message.

We expected formal school education to lead to improved response because: (1) we expected formal school education to lead to a better ability to access, understand, and interpret cyclone early warning messages, and (2) we expected formal school education to lead to greater income, which in turn would mean a greater access to resources for evacuation, e.g., vehicles for transportation, and hence a better response to the warning. The results show that the relationship between formal education and evacuation is not as strong as expected and in fact disappears completely as definition of appropriate response (evacuation) is made stricter.
Let us first consider income and socioeconomic status. The positive and significant correlation in our study between education and income is in conformance with literature on education and its effect on positive life outcomes; Sharma (2009) showed a positive and significant correlation between education and income even though the magnitude of correlation was not very high. However, the question of direction of causality, i.e., whether greater education causes greater income or having a greater income provides an opportunity for more number of years in school, remains unresolved. The original study (Sharma 2009) on which this paper draws, was not designed to resolve this question. However, given the positive correlation between education and income, it seems surprising and perhaps counterintuitive that for evacuation decisions, income does not seem to matter either for all respondents or across different categories of education. However, we need to acknowledge that the ability to respond better because of the 'income effect' could not be explored adequately in this paper because there was not enough variance in the incomes of the sample of respondents. For example, if one considers the income distribution across the sample, which is representative of the affected coastal population, then one can see that the income levels are not very high in general. In fact qualitative data revealed that people often depend on transportation provided by the government to evacuate out of the village. The village-wise data collected on average assets in the village also revealed that the resources for evacuation such as transportation are on 
Table 4. Bivariate logistic regression of evacuation predictors on evacuation among all respondents and separately by presence or absence of traditional knowledge base.

\begin{tabular}{|c|c|c|c|}
\hline \multirow[b]{2}{*}{ Independent variables } & \multicolumn{3}{|c|}{ Voluntary shelter evacuation } \\
\hline & $\begin{array}{l}\text { All respondents } \\
\quad(\mathrm{N}=212)\end{array}$ & $\begin{array}{c}\text { Respondents without } \\
\text { traditional knowledge } \\
\text { base }(\mathrm{N}=111) \\
\end{array}$ & $\begin{array}{c}\text { Respondents with } \\
\text { traditional knowledge base } \\
(\mathrm{N}=101)\end{array}$ \\
\hline \multicolumn{4}{|c|}{ Indicators related to access, understanding, and interpretation of warning information } \\
\hline Severity of cyclone & $2.42 * * *$ & 1.289 & $5.82 * * *$ \\
\hline Landfall location of cyclone & $2.61 * * *$ & 1.71 & $4.07 * * *$ \\
\hline Landfall time of cyclone & $2.35^{* * * *}$ & 1.43 & $4.07 * * *$ \\
\hline Evacuation order in the warning & 1.51 & 1.28 & 1.57 \\
\hline Protective guidance in the warning & $2.28 * * *$ & $3.07 * * *$ & 1.56 \\
\hline Clarity of the warning message & $2.36^{* * * *}$ & $1.96 *$ & $2.57 * *$ \\
\hline Type of channel & $2.03 * *$ & 1.5 & $2.77^{*}$ \\
\hline Estimate of damage due to cyclone given a particular severity & $1.73 * *$ & 1.012 & $3.73 * * *$ \\
\hline \multicolumn{4}{|c|}{$\begin{array}{l}\text { The number in the cells are exponentiated betas or odds ratios. An odds ratio of } 1 \text { (or not significantly different from } 1 \text { ) indicates no effect. An odds ratio } \\
\text { larger (or smaller) than } 1 \text { indicates factor by which odds of evacuation are increased (or decreased) by one unit change in independent variable. } *, * *, * * * \\
\text { represent the level of significance (alpha) } \\
* * * \text { implies alpha } \leq 0.01 \\
* * \text { implies alpha } \leq 0.05 \\
* \text { implies alpha } \leq 0.10\end{array}$} \\
\hline
\end{tabular}

the whole quite scarce in these villages. Unless the cyclone shelter is in walking distance, the means of transportation for evacuating are rather limited. This aspect could perhaps be explored in future studies.

However, one needs to be cautious about assertions that better socioeconomic status can lead to a better capacity to respond to risk. This positive relationship may not always be true as the results with respect to housing quality reveal in this paper. Better housing quality had actually led to reduced response to warning among the higher educated respondents. Better housing quality probably made these respondents feel safe in their homes. This may have been a fatal decision on the part of the respondents if Ogni and Fanoos had continued to be severe cyclones, instead of lowering in intensity before crossing land. Sometimes a better socioeconomic status may give a false sense of protection against the risk.

Table 5. Cross-tabulation of respondents by level of education and possession of traditional knowledge for predicting cyclones.

\begin{tabular}{lcc}
\hline $\begin{array}{l}\text { Years of } \\
\text { education }\end{array}$ & $\begin{array}{c}\text { Without traditional } \\
\text { knowledge }\end{array}$ & $\begin{array}{c}\text { With traditional } \\
\text { knowledge }\end{array}$ \\
\hline 0 & 27 & 16 \\
1 to 10 & 58 & 69 \\
11 or more & 26 & 16 \\
\hline
\end{tabular}

To explain the unexpected positive effect of housing quality on evacuation in the case of illiterate respondents, we dug deeper into the data and found that a greater proportion of illiterates who had good quality housing also had access to a cyclone shelter nearby, whereas the greater proportion of people who had poor quality housing also tended not to have a cyclone shelter nearby. This brings to fore the importance of appropriate infrastructure and its effect on response to risk, particularly in the case of populations with lower levels of socioeconomic means, as is the case in our study.

With respect to access, understanding, and interpretation of the warning, the results are also unexpected and counterintuitive. Based on literature in the area of adaptation to climate change (i.e., Norris and Bati 1987, Igoden et al. 1988, Lin 1991, Maddison 2006, Deressa et al. 2008) and literature on warning response (e.g., Edwards 1993, Farley et al. 1993, Liu et al. 1996, Balluz et al. 2000) we expected that the respondents with more formal education would be able to better access, understand, and interpret warning messages. The results revealed that education did seem to make a difference in this regard when compared to noneducated respondents. However, the results were counterintuitive because the effects were not observed consistently in cases of different categories of educated people. For example, we considered reporting of warning message content, i.e., cyclone severity, landfall location, landfall time, evacuation order, and protective guidance, by respondents as an indicator of understanding because recall of the message content reflects at least some understanding. Those respondents who recalled receiving information on cyclone severity, landfall location, and landfall time in the warning message had a greater chance of heeding the warning and evacuating for the whole sample, but across different categories of education, only for the category with 1 to 10 years of education and not for the illiterates and 11 or more years of education categories. This seems counterintuitive because one would expect the more educated (11 or more years) to have understood the message even better and hence to have evacuated. 
By contrast, nonformal forms of education, i.e., a traditional knowledge base for predicting cyclones based on environmental precursors, was much more relevant in terms of understanding and interpreting warning information. For example, in the context of the point made in the above paragraph, when we considered the nonformal education we found that message content, with the exception of protective guidance, significantly and positively influenced evacuation among the respondents who possessed traditional knowledge and did not affect evacuation for those who did not possess traditional knowledge. This probably happened because their own understanding of the occurrence of the cyclone that they gleaned from the environmental precursors helped them trust, understand, and interpret the warning information better. This finding in addition with the fact that there was a greater prevalence of traditional knowledge among respondents with 1 to 10 years of education seem to explain the counterintuitive result that cyclone severity, landfall location, and landfall time are significant predictors of evacuation among respondents with education between 1 and 10 years and not for people with higher levels (11 or more years) of education.

However, an observation of the study is that formal education correlated to deterioration in traditional knowledge for predicting cyclone occurrence based on environmental precursors. Qualitative data revealed that there has been deterioration in the traditional knowledge base as more and more people go into the formal higher education system. With formal education not playing a strong role in the correct interpretation of warning messages because it is usually not hazard specific, combined with the deterioration in the traditional knowledge base, the warning recipients tend to follow a wait and see approach and the decision to evacuate is often made when it is too late to evacuate.

Our study makes a contribution to the literature on adaptation to climate change, disaster risk reduction, and warningresponse and evacuation literature in a two different ways: first, it suggests that whether formal education is a determinant of adaptive capacity is not a straightforward question. Although formal education may provide greater access to income earning opportunities and may enhance welfare in general, it is the hazard-specific knowledge and understanding gained from nonformal sources that tends to play a greater role in responding appropriately to hazard risk. Hence, there is value in preserving and promoting the traditional knowledge base along with greater enrolment in the formal education system.

Second, it makes a contribution to warning-response literature because it seems to be the first study that attempts to study the role of traditional knowledge in evacuation decisions. The only study that addressed the issue of traditional knowledge in evacuation decisions is Westgate (1978) but even this study only documents some of the environmental precursors people reported observing before a cyclone and does not attempt to examine whether these had any effect on evacuation decision or not. Similarly, as discussed earlier, the literature so far has mostly documented different indicators used by people for their decision making without actually examining whether use of such traditional knowledge indicators actually led to better decisions or not. In this study we attempt to address this issue and found that possession of traditional knowledge could lead to better decision making and outcomes with respect to adaptive behavior, i.e., evacuation. Also it seemed to complement the warning message based on the modern scientific expert knowledge system (meteorology). However, whether traditional knowledge systems and modern scientific knowledge systems as reflected in the forecasts of the meteorology department would always complement each other or may at times even contradict each is an empirical question which needs further investigation and research.

Responses to this article can be read online at: http://www.ecologyandsociety.org/issues/responses. php/5439

\section{Acknowledgments:}

This paper has benefited from discussions with Prof. D. Parthasarathy, Dr. Joanne Bayer, Dr. Jan Sendzimir, and Dr. William Butz and the authors are deeply thankful to them for their insights. The authors are deeply grateful to Mr. R. Sivakumar (Jt. Commissioner, Revenue Department, Government of Tamil Nadu), Mr. GaganDeep Singh Bedi (Collector, Cuddalore, 2006), Mrs. G. Jayalakshmi (Collector, Guntur, 2007), Mrs. Udayalakshmi (Collector, Prakasam, 2007), Mr. Navin Mittal (Collector, Krishna, 2007), Mr. Sampath Kumar (Jt. Collector, Krishna, 2005), Mr. Sundara Raju (District Revenue Officer, Krishna, 2005), and the language interpreters Mr. Victor Paul, Mr. Vellumani, Mr. Sadan, Ms. Someshwari, Mr. Trinadha Reddy, and Mr. Srinivasan, all of whom provided invaluable support and assistance at various stages of the fieldwork, as well as many respondents who warmly welcomed the first author into their homes and gave their time in answering her questions. This research was made possible through support from Advanced Institute on Vulnerability to Global Environmental Change, a program funded by the David and Lucille Packard Foundation and coordinated by START in partnership with IIASA; the U. $S$. National Science Foundation's cooperative agreement with Carnegie Mellon University (SBR-9521914); and the postdoctoral program at the International Institute for Applied Systems Analysis. Any remaining errors of fact or analysis in the paper are those of the authors. 


\section{LITERATURE CITED}

Acharaya, S. 2011. Prediction of rainfall variation through flowering phenology of night flowering jasmine (Nictanthes arbor-tristis L., Verbenaceae) in Tripura. Indian Journal of Traditional Knowledge 10(1):96-101.

Adams, P., M. D. Hurd, D. McFadden, A. Merrill, and T. Ribeiro. 2003. Healthy, wealthy, and wise? Tests for direct causal paths between health and socioeconomic status. Journal of Econometrics 112(1):3-56. http://dx.doi. org/10.1016/S0304-4076(02)00145-8

Adger, W. N., N. Brooks, G. Bentham, M. Agnew, and S. Eriksen. 2004. New indicators of vulnerability and adaptive capacity. Technical Report 7. Tyndall Centre for Climate Change Research, University of East Anglia Norwich, UK.

Anandaraja, N., T. Rathakrishnan, M. Ramasubramanian, P. Saravanan, and N. S. Suganthi. 2008. Indigenous weather and forecast practices of Coimbatore district farmers in Tamil Nadu. Indian Journal of Traditional Knowledge 7 (4):630-633.

Angchok, D., and V. K. Dubey. 2006. Traditional method of rainfall prediction through almanacs in Ladakh. Indian Journal of Traditional Knowledge 5(1):154-150.

Angrist, J. D., and A. B. Krueger. 1991. Does compulsory school attendance affect schooling and earnings? Quarterly Journal of Economics 106(4):979-1014. http://dx.doi. org/10.2307/2937954

Baker, D. P., J. Leon, E. G. Smith Greenaway, J. Collins, and M. Movit. 2011. The education effect on population health: a reassessment. Population and Development Review 37:307-332. http://dx.doi.org/10.1111/j.1728-4457.2011.00412. $\underline{x}$

Balluz, L., L. Schieve, T. Holmes, S. Kiezak, and J. Malilay. 2000. Predictors for people's response to a tornado warning: Arkansas, 1 March 1997. Disasters 24(1):71-77. http://dx.doi. org/10.1111/1467-7717.00132

Barro, R. J. 2001. Human capital and growth. American Economic Review 91(2):12-17. http://dx.doi.org/10.1257/ aer.91.2.12

Barro, R. J., and J.-W. Lee. 2001. International data on educational attainment: updates and implications. Oxford Economic Papers 53(3):541-563. http://dx.doi.org/10.1093/ oep/53.3.541

Bateman, J. M., and B. Edwards. 2002. Gender and evacuation: a closer look at why women are more likely to evacuate for hurricanes. Natural Hazards Review 3:107-117. http://dx.doi.org/10.1061/(ASCE)1527-6988(2002)3:3(107)

Becker, G. S. 1964. Human capital: a theoretical and empirical analysis, with special reference to education. University of Chicago Press, Chicago, Illinois, USA.
Blankespoor, B., S. Dasgupta, B. Laplante, and D. Wheeler. 2010. The economics of adaptation to extreme weather events in developing countries - Working paper 199. Center for Global Development, Washington, D.C., USA.

Caldwell, J. C. 1979. Education as a factor in mortality decline: an examination of Nigerian data. Population Studies 33:395-413. http://dx.doi.org/10.2307/2173888

Chinlampianga, M. 2011. Traditional knowledge, weather prediction and bio-indicators: a case-study in Mizoram, Northeastern India. Indian Journal of Traditional Knowledge 10(1):207-211.

Clay, D., T. Reardon, and J. Kangasniemi. 1998. Sustainable intensification in the highland tropics: Rwandan farmers' investments in land conservation and soil fertility. Economic Development and Cultural Change 46(2):351-377. http://dx. doi.org/10.1086/452342

Cochrane, S. H., D. J. O'Hara, and J. Leslie. 1980. The effects of education on health. Working Paper No. 405. The World Bank, Washington, D.C., USA.

Cohen, D., and M. Soto. 2007. Growth and human capital: good data, good results. Journal of Economic Growth 12:51-76. http://dx.doi.org/10.1007/s10887-007-9011-5

Cutter, S. L., B. J. Boruff, and W. L. Shirley. 2003. Social vulnerability to environmental hazards. Social Science Quarterly 84(2):242-261. http://dx.doi.org/10.1111/1540-6$\underline{237.8402002}$

Deressa, T. T., R. M. Hassan, T. Alemu, M. Yesuf, and C. Ringler. 2008. Analyzing the determinants of farmers' choice of adaptation methods and perceptions of climate change in the Nile Basin of Ethiopia. IFPRI Discussion Paper No. 00798, International Food Policy Research Institute, Washington, D. C., USA.

Edwards, M. L. 1993. Social location and self-protective behavior: implications for earthquake preparedness. International Journal of Mass Emergencies and Disasters 11 (3):293-303.

Farley, J. E., H. D. Barlow, M. S. Finkelstein, and L. Riley. 1993. Earthquake hysteria, before and after: a survey and follow-up on public response to the Browning Forecast. International Journal of Mass Emergencies and Disasters 11 (3):305-321.

Hanushek, E. A., and D. D. Kimko. 2000. Schooling, laborforce quality, and the growth of nations. American Economic Review 90(5):1184-1208. http://dx.doi.org/10.1257/aer.90.5.1184

Igoden, C., P. Ohoji, and J. Ekpare. 1988. Factors associated with the adoption of recommended practices for maize production in the Lake Basin of Nigeria. Agricultural Administration and Extension 29(2):149-156. http://dx.doi. org/10.1016/0269-7475(88)90013-X 
Irfanullah, H. M., and A. Motaleb. 2011. Reading nature's mind; disaster management by indigenous peoples of Bangladesh. Indian Journal of Traditional Knowledge 10 (1):80-90.

Jamison, E. A., D. T. Jamison, and E. A. Hanushek. 2007. The effects of education quality on income growth and mortality decline. Economics of Education Review 26:771-788. http:// dx.doi.org/10.1016/j.econedurev.2007.07.001

Kanani, P. R., and A. Pastakia, 1999. Everything is written in the sky!: Participatory meteorological assessment and prediction based on traditional beliefs and indicators in Saurashtra. Eubios Journal of Asian and International Bioethics 9:170-176.

Lin, J. Y. 1991. Education and innovation adoption in agriculture: evidence from hybrid rice in China. American Journal of Agricultural Economics 73(3):713-723. http://dx. doi.org/10.2307/1242823

Liu, S., L. E. Quenemoen, J. Malilay, E. Noji, T. Sinks, and J. Mendlein. 1996. Assessment of a severe-weather warning system and disaster preparedness, Calhoun County, Alabama, 1994. American Journal of Public Health 86(1):87-89. http:// dx.doi.org/10.2105/AJPH.86.1.87

Lochner, L. 2004. Education, work, and crime: a human capital approach. International Economic Review 45:811-843. http:// dx.doi.org/10.1111/j.0020-6598.2004.00288.x

Lutz, W., and S. KC. 2011. Global human capital: integrating education and population. Science 333(6042):587-592. http:// dx.doi.org/10.1126/science.1206964

Maddison, D. 2006. The perception of and adaptation to climate change in Africa. CEEPA. Discussion Paper No. 10. Centre for Environmental Economics and Policy in Africa, University of Pretoria, Pretoria, South Africa.

Mao, A. A., and M. Hynniewta. 2011.Plants used as agricultural seasons indicator by Mao Naga tribe, Manipur, India. Indian Journal of Traditional Knowledge 10 (3):578-580.

Mazza, G. 2007. The interaction between formal and nonformal education - the objective of raising the employability of young people. European Journal on Youth Policy 10.

McGray, H., A. Hammill, and R. Bradley. 2007. Weathering the storm options for framing adaptation and development. World Resource Institute, Washington D.C., USA.

Mileti, D., R. Bandy, L. B. Bourque, A. Johnson, M. Kano, L. Peek, J. Sutton, and M. Wood. 2006. Annotated bibliography for public risk communication on warnings for public protective actions response and public education. University of Colorado, Boulder, Colorado, USA. [online] URL: http:// www.colorado.edu/hazards/publications/informer/infrmr2/ pubhazbibann.pdf

Mileti, D. S., and J. DeRouen Darlington. 1997. The role of searching in shaping reactions to earthquake risk information. Social Problems 44:89-103. http://dx.doi.org/10.2307/3096875

Mileti, D. S., J. DeRouen Darlington, C. Fitzpatrick, and P. W. O'Brien. 1993. Communicating earthquake risk: societal response to revised probabilities in the Bay Area. Hazards Assessment Laboratory, Department of Sociology, Colorado State University, Fort Collins, Colorado, USA.

Nedelcheva, A., and Y. Dogan. 2011. Uasge of plants for weather and climate forecasting in Bulgarian folk traditions. Indian Journal of Traditional Knowledge 10(1):91-95.

Nie, N. H., J. Junn, and K. Stehlik-Barry. 1996. Education and democratic citizenship in America. University of Chicago Press, Chicago, USA.

Norris, E., and S. Batie. 1987. Virginia farmers' soil conservation decisions: an application of Tobit analysis. Southern journal of Agricultural Economics 19(1):89-97.

Oreopoulos, P. 2003. Do dropouts drop out too soon? Evidence from changes in school-leaving laws. NBER Working Paper 10155. National Bureau of Economic Research, Cambridge, Massachusetts, USA.

Oswald, A., and N. Powdthavee. 2007. Death, happiness, and the calculation of compensatory damages. IZA Discussion Paper 3159. Institute for the Study of Labour, Bonn, Germany.

Pareek, A., and P. C. Trivedi. 2011. Cultural values and indigenous knowledge of climate change and disaster prediction in Rajasthan, India. Indian Journal of Traditional Knowledge 10(1):183-189.

Patt, A., P. Suarez, and C. Gwata. 2005. Effects of seasonal climate forecasts and participatory workshops among subsistence farmers in Zimbabwe. Proceedings of the National Academy of Sciences of the United States of America 102:12623-12628. http://dx.doi.org/10.1073/pnas.0506125102

Patt, A. G., M. Tadross, P. Nussbaumer, K. Asante, M. Metzger, J. Rafael, A. Goujon, and G. Brundrit. 2010. Estimating least developed countries' vulnerability to climaterelated extreme events over the next 50 years. Proceedings of the National Academy of Sciences of the United States of America 107:1333-1337. http://dx.doi.org/10.1073/pnas.0910253107

Rengalakshmi, R. 2006. Harmonizing traditional and scientific knowledge systems in rainfall prediction and utilization. Chapter 12 in W. Reid, F. Berkes, T. J. Wilbanks, and D. Capistrano, editors. Bridging scales and knowledge systems: concepts and applications in ecosystem assessment. Island Press, Washington, D.C., USA. 
Samati, H., and S. S. Begum. 2006. Plant indicators for agricultural seasons amongst Pnar tribe of Meghalaya. Indian Journal of Traditional Knowledge 5(1):57-59.

Sethi, S. N., J. K. Sundaray, A. Panigrahi, and S. Chand. 2011. Prediction and management of natural disasters through indigenous technical knowledge, with special reference to fisheries. Indian Journal of Traditional Knowledge 10 (1):167-172.

Sharma, U. 2009. Enhancing adaptive capacity to climate risk. Dissertation. Indian Institute of Technology, Bombay, India.

Sharma, U., A. Patwardhan, and D. Parthasarathy. 2009. Assessing adaptive capacity to tropical cyclones in the East coast of India: a pilot study of public response to cyclone warning information. Climatic Change 94(1-2):189-209. http://dx.doi.org/10.1007/s10584-009-9552-z

Singh, H. B. 2011. Plants associated in forecasting and beliefs within the Meitei community of Manipur, Northeast India. Indian Journal of Traditional Knowledge 10(1):190-193.

Singh, R. K., and A. Dorjey. 2004. Farming proverbs: analysis of their dynamics and farmers' knowledge. Indian Journal of Traditional Knowledge 3(3):276-286.

Singh, D., and R. K. Singh. 2011. Kair (Capparis decidua): a potential ethnobotanical weather predictor and livelihood security shrub of the arid zone of Rajasthan and Gujarat. Indian Journal of Traditional Knowledge 10(1):146-155.

Sivaprakasam, S., and V. Kanakasabai. 2009. Traditional almanac predicted rainfall - a case study. Indian Journal of Traditional Knowledge 8(4):621-625.

Soto, M. 2006. The causal effect of education on aggregate income. Working Papers 0605, International Economics Institute, University of Valencia, Valencia, Spain.

Spence, M. 1973. Job market signaling. Quarterly Journal of Economics 87(3):355-374. http://dx.doi.org/10.2307/1882010

Stiglitz, J. E. 1975. The theory of screening, education, and the distribution of income. American Economic Review 65:283-300.

Teron, R., and S. K. Borthakur. 2009. Traditional knowledge related to use of flora and fauna as indicators in predicting annual seasons among Karbi tribe of Assam. Indian Journal of Traditional Knowledge 8(4):518-524.

Toya, H., and M. Skidmore. 2007. Economic development and the impacts of natural disasters. Economics Letters 94:20-25. http://dx.doi.org/10.1016/j.econlet.2006.06.020

Turner, R. H., J. M. Nigg, D. H. Paz, and B. S. Young. 1979. Earthquake threat: the human response in Southern California. Institute for Social Science Research, University of California, Los Angeles, USA.
Turner, R. H., J. M. Nigg, D. H. Paz, and B. S. Young. 1981 Community response to earthquake threat in Southern California, Part 10, Summary and Recommendations. Institute for Social Science Research, University of California, Los Angeles, USA.

United Nations Development Programme (UNDP). 2004. A global report: reducing disaster risk - a challenge for development. UNDP, Bureau for Crisis Prevention and Recovery, New York, New York, USA.

Vanadeep, K., S. S. Murty R., and M. Krishnaiah. 2012. Meteorological predictions preserved in the Panchangam versus real-time observations - a case study over Tirupati region - a semi-arid tropical site in India. Indian Journal of Science and Technology 5(4):2491-2509.

Verba, S., K. L. Schlozman, and H. E. Brady. 1995. Voice and equality: civic voluntarism in American politics. Harvard University Press, Cambridge, Massachusetts, USA.

Westgate, K. 1978. Hurricane response and hurricane perception in the Commonwealth of the Bahamas. Mass Emergencies 3(4):251-265.

Wisner, B., P. Blaikie, T. Cannon, and I. Davies, 2003. At risk - natural hazards, people's vulnerability and disasters. Routledge, New York, New York, USA. 